and conferences, to provide contacts between its members and those of other national and international associations with interests in the same field, to promote research and writing in African law, and generally to assist in the development of the legal profession and legal education in Africa as far as feasible and desirable. The Association is co-operating with the African Law Committee of the American Bar Association and newsletters are circulated from time to time; permission has also been obtained to distribute to the members a preliminary draft of an African law bibliography which is being prepared for the Libraries Study Project of the A.A.L.S. The dues for individual membership are $\$ 5$ per annum. Persons interested should write to Professor A. Arthur Schiller, Columbia University School of Law, Box 31, 435 West ir6th Street, New York, New York roo27. The first newsletter was published on 25 April 1965.

\title{
African Studies at the Frobenius-Institut, Frankfurt (Main)
}

Professor Dr. Carl Smitz, formerly Director of the Ethnographical Museum at Basle, was appointed Director of the Frobenius Institut shortly before the deeply regretted death of Professor Dr. Adolf Jensen in May this year. Under Professor Smitz's direction the Institute hopes to carry on its tradition of work on the culture history and cultural anthropology of African peoples, in which it has so long been interested, in the tradition of the outstanding work of Frobenius and Jensen.

Dr. E. Haberland, formerly on the Africanist staff of the Institute, has been appointed Professor Ordinarius at the University of Mainz; Dr. H. Straube will, it is hoped, remain in Frankfurt. Work on African studies is being undertaken by Dr. Hildegard Klein, Dr. Barbara Frank, Dr. Andreas Kronenberg, Dr. Walter Resch, and Mr. E. Hagolani. Dr. Frank is also working on a programme to popularize knowledge of African peoples among the German public. Dr. Kronenberg, formerly Government Anthropologist in Khartoum, is working on his researches in the Sudan. Dr. Resch, a specialist in rock-paintings, on which he did field research in Nubia, is in charge of the Institute's large unpublished collection.

The Institute's journal Paideuma would welcome more papers from colleagues abroad in order to present some of the different approaches in Europe and the United States to common problems. Papers can be either translated or given a full summary in German. The address of the Frobenius-Institut is: Frankfurt (Main), Liebigstrasse 4I.

\section{Programmed Learning Research in Central Africa}

DuRING the past eighteen months rapid strides have been made in establishing programmed learning research in Central Africa. At the University College in Salisbury there are firstclass library facilities for persons working in this field, with some 250 programmed texts, a collection of teaching machines, about 80 books concerning programmed learning, and nearly 200 research reports (from many countries) now available.

Within the Faculty of Education, Dr. D. G. Hawkridge and a number of assistants are preparing or adapting programmes and testing them in African schools, mostly at the junior secondary level. In time it is hoped to be able to assist in the further education of poorly qualified primary school teachers in the African sphere. Industrial training is being actively considered too. Seminars and conferences are held regularly, and programmed learning features as a topic in the syllabuses of all I60 students (mostly postgraduate) in the Faculty. A quarterly information bulletin is available free of charge from Dr. Hawkridge at P. Bag $167 \mathrm{H}$, Salisbury. 